based and market-driven solutioms lo environmentat problems. The report endorsed more cooperative partmerships between fed eral, state, local, public and private sectors. Derr said the report achnowledger that there has to be more solving to our environmental problems that pitting one interest group against another.

Rohert Lindblom, of the Californiat Board of Registration for Geologists and Geophysictsts, gave his view on Californial 's eeneration of experience with licensing of professional earth scientists at dhe Division of Professional Aftarrs luncheon. Acknowl edging the controversial topic of registrattion, Lindblom asked. Is it fair to generatise that resource geologists tend to have serious concerns about government regulation. whereas engineering and related geologists share those concerns but are willing to accept regulation by licensure becaluse they see the benelits to society or to the public being worth more that the costs to the prolession?" Lindblom predicted that "all of the most populated states will adopt some form of reasistration by the turn of the century.

A morning secsion of 3-1)/4. D model ing and visualisation, featured interatetive computer images projected on two large sereens, giving presenters the ability to demonstrate actual computer techniques for the attendees a prime cxample of culting edge technology

Brisk activity also was reported in the Deal Room Prospect (iallery. sponsored by the Division of Professional Aflates, where individuats and companies strutted their prospects for potential partners.

The high attendance for all activities and enthusiasm for the scheduled events spoke volumes about the "positive feeling" in San Diego. Indications are that this atmosphere will continue until the 1997 ammual meeting to be held in Dallas on April 6-9. In the words of President Reid. "The" good times will come again.

\section{Barbara $\mathrm{McCoy}$}

MPC $;$, Tulsw OK LSA

\section{Networking amongst Himalayan researchers}

Himalayan geology is increasingly drawing the attention of the international geological community. In response to this "global age of Himalayan geology", several community services and information networks have appeared in recent years. Recently, we conducted an intcrnational survey among IImalayan researchers to evaluate how they use these resources, and to find what improvements can be made to them. The survey was sent out in February 199610 some 500 active Himalayan rescarchers in various countries. There was a truly international participation, reflecting the current ranne of researchers from many countries. The survey was also posted twice on the electronic mail newwork HimNet (4 and 25 Fehruary, 1996), which is used by 580 researchers. There is a large overlap between our survey datiabase list and the HimNet subscription list. A total of 258 replies to the survey were received, which account for nearly $40 \%$ of our mailing list there we briefly report on the survey since the ideas and results derived maly also be useful for development of networks and community services in other lields ol geofogical nescarch and scientilic activity.

\section{HimNet (Himalayan Network)}

MimNer (llimNed(rerdw.ethr.eh) is an eMail Internet link for researchers working in the Himalayan region (Afghanistan. Pak istall. China, India, Nepal, Bhutan.

Bangladesh and Burmat). It aims to provide a rapid method of communication and dis senumation of information on Himalayan geosciences. IIimNet sends dired e-mail to its subseribers. Launched by David $A$ Spencer in August. 1994. with an initial subseription of 40 people, the number of subseribers has increased 10.580 (rigure 1 ).

By May, 1996, 27 mews packages had bectn semt of subscribers in 32 countries. Although predominantly related to the Gensciences. Himalay an researchers in several other licdes (from hiology to linguistice) have also subscribed last year, a World Wide Webllome Page (hatp://ww lehigh.

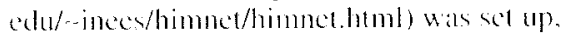
and is maintained by Petor $\mathrm{K}$ Keitler $\mathrm{l}$. chigh (niversity. USA) allowing acess to all the bach issues of HimNet hrough the WWW or J TP (fip to dharma.geo. lehigh.edu; User II): anonymous: Password: your e-mail address: Directory:/pub/himnet).

Virtually all of those who responded to the survey (92\%) knew about HimNet: $66 \%$ were subscribers. Of the $34 \%$ who were not. most cited the lack of internet connection as

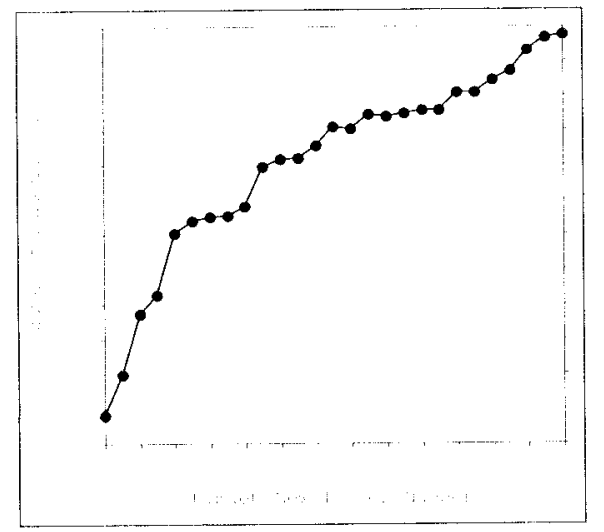

Figure I Subscribers to HimNet the matin reason for not joining (6.3\%). This was especially so in the Himalayan countries. where internet connections are not available, too expensive or depecnd on official permission. Other reasons for not subscribing 10 HimNet included phobias to mailing lists. the fact that the postings took up too much disk space or simply not having time to read it.

The most popular features of Him Net are the Latest Himalayan Papers (91\%). Latest flimalayan Books $(85 \%)$ and Conference Announcements $(82 \%)$. It seems that subscribers use HimNe't mainly als a source of information rather than as a medium for discussion. This is also clear from the fact that nearly two thirds of those subscribed $162 \%$ ) had never mate a contribution to HimNet. Nevertheless. $96 \%$ of the subseribers thought that HimNet is a valuable research $1001: 61 \%$ rated it as excellem and $34 \%$ as gond.

\section{IIimalayan Notes}

Himelerem Notes is an international news hulletin on the earth and environmental sciences of the Ilimalaya-Tibetan region. founded in carly 1993 by Rasoul B Sorkhabi. Himalaven Notes is published wice a year in March and September. Himalaram Notes attempts to present up-todate infomation on south-central Astat is geoseiences, provide a platform tor discussions and exchange of ideas and act as an informational bridge hetween Himalayan and toreinn scientists. At present. Himalayam Notes is coordinated by a group of regional editors (in Europe, India. Pakistan. and Nepal) and a matraging editor in the USA.

Nearly $78 \%$ of the people surveyed were aware of Himalaran Notes, although only 26\% subscribed to it. mainly bacause of international payment problems. The most popular features of Himalaran Notes are the Research line (read by $98 \%$ of subxribers). Conference Reports $(89 \%$ ). Book keviews $(89 \%)$, In brief $(86 \%)$ and in press $(82 \%)$. Only half of those subscribed read the travel accounts $(52 \%)$ and articles about the institutions $(48 \%)$. Therefore, the subscribers used Himalaran Notes mainly as a source of research information, rather than a magarine with feature articles. Similar to HimNet. 57\% of the subseribers had never made a contribution to Himalayan Notes. Nevertheless. $93 \%$ of them thought that Himalesam Noles was a valuable information tool and $7.5 \%$ were content with it being published fwice a year $18 \%$ stgegested that the frequency of publication should he increased to four times a year). Although Himalayan Note's is prodominanty seen as at source of research information, a clear $95 \%$ agreed that social issues and eultural aspects of the Himalayan region may be addressed in Himalavan Noles from a scientitic stand point and with regard to the matural environment. Most subseribers seem to be satistied with Himalavan Nores, mating it good $168 \%$ ) or excellent $(27 \%)$. 
Himalaya-Karakoram-Tibet workshops

Initiated by Michael P Searle, in 1985. 11 Himalaya-Karakoram-Tibel (HKT) Workshop have been held. These workshops continue to be one of the main forums and the proceedings volumes form an excellent source of up-to-date geological information on th region.

Virtually everyone who responded to the survey (98\%) knew about the HKT workshops and $57 \%$ had attended at least one of them. The majority of people $(89 \%)$ had made a presentation (either oral or poster). indicating that the workshops are clearly seen als a "participation", rather than a "spectitor", event. The workshops are also used als an opportunity to meet colleagues (9) \% ) listen to lectures $(94 \%)$ and discuss Himalayam issues $(91 \%)$. Although only $56 \%$ were interested in the publication of the proceedings volumes over $72 \%$ had reterred to at least one of the papers published. Nearly half $(43 \%)$ of those who had attended the workshops considered them too expensive. Nevertheless, $82 \%$ considered that they are an important event in their research calender.

Perhaps one of the most surprising results was that nearly two thirds $(6.5 \%)$ suggested that the workshops be held once every two years rather than every year (supported by $32 \%$ ). There were even a few suggestions for holding the workshop every four years! The main reason for wanting tewer workshops was that becaluse they ane too frequent, there is a tendency for delegates to repeat the previous year"s talk". A suggestion was also made that because every country is expensive for someone from somewhere, then the workshop should (as has been in the last three years) be rotated every year to different continents so that all would have a chance to allend. This is only fair". To date. nine of the 11 meetings have been in Europe. Overall, 57\% thought the workshop have been 'good' and $43 \%$ rated them 'excellent'.

\section{International Society of Himalayan Geoscientists}

Recently, Ratsoul Sorkhabi has suggested that there is a need for an International Soci ety of Himalayan Geoscientists because, as history shows, scientific disciplines are better developed when their respective communities have become organised, with efficient ways of exchanging information, regular publications and meetings. $72 \%$ of those who responded to the survey agree. Such a society should mainly be involved in organising the Himalaya Karakoram-Tibet Workshops $(93 \%$ ). promoting the imporlance of research in the Himalayan regions $(88 \%)$ and representing the scientific community $(76 \%)$. Its other goals may include publishing a newsletter $(7.5 \%)$. publishing a research journal $(68 \%)$ and ruming an electronic neiwork system (82\%). Although not seen necessarily as a funding agent, 76\% especially those from the Himalayan countries) suggested that such a Society should try to arrange funds from international or western world funding agencies to enable students and researchers from the Himalayan countries to attend international meetings. Hall ( $53 \%$ ) of those who supported the idea of an International Society for Himalayan Geoscientists are willing to be involved in its establishnent.

However, there were also sone arguments against the formation of such a society. For example: 'Such organisations divert energy away from research": Official organisations actually hinder cooperation. especially between young and old scientists"; "No need for anther society. A formal organisalion would not improve our situation unless a lot of elfort and lime is devoted to it." Most of those who were against the formation of a Society were the more establistred and experienced Himalayan geologists from Europe or the US $\wedge$. while virtually all of the researchers from the Himalianan countries supported the idea.

\section{Summary and concluding remarks}

I Overall, the Himalayan research commu. nity appreciates the importance of networks and information resources available to them: however, only a minority of them actively contribute to the community services.

2 Both HimNet and Himalavan Noles are relative neweomers to the Ilimalayan research scene. IlimNet is lirec of charge. while Himalaran Notes requires a subscription fees to cover costs. This. and the fact that HimNet is a lister method of communication, are the main reasons for the large disparity between the numbers of their subscribers. Nevertheless, both enjoy much support. Subscribers use them latecly to obtain information rather than for discussion. Since both HimNet and Himalavan Notes are produced by the voluntary efforts of several individuals. their future activity cannot be ensured unless they are run commercially or rolated voluntarily among active Himalayan researchers. The establishment of an International Society for Himalayan Geoscientists would provide chamnels for such voluntary effort.

3 The llimalaya Karakoram-Tibel workshops are seen as the main gathering opportunity for mosit Himalayan researchers. Nevertheless, the majority of the surveyed people thought that they are too frequent. Although the idea of holding the workshops every two years needs to be closely examined. it should be noted that over the past decade, the annual meetings have become increasingly popular and have produced a large amount of geological publications on the Himalayan region (liew tectonic regions and geological workshops have been so prolific).

4 Most rescarchers support the idea of the creation of an International Society of Ilimalayan Geoscientists. Nevertheless, to suceed it would require a great deal of time and enerey. As history shows, most of the scientific and professional societies were founded through the cooperation of a lew pioneer. like-minded individuals. not necessatrily the consensus of a whole commenily. Indeed. the majority suppont of the Himalayan rescarch community for founding a society is a very positive sign. Other specialised periodicals such as the Jemmal of Himalayan Geology (published semi-annually by the Wadia Institule of Himalityan Geology, India) and the Himalayan Resedard Bulletin (two semi-annual periodicals in North America and Europe which locus on social sciencest, can form vital clements of any international society. but they are currently scattered mini islands that could better develop under the umbrella of an international socicly with high scientific and democrallic standards.

\section{Acknowledgements}

We would like to thank all those who responded to the Survey of Himalayan Resources.

\section{David A Spercer}

Institume of Goology. Swiss Federal linstitule of Terhmology, (11-8092, Ziirich, Switzorland

\section{Rasoul B Sorkhabi}

Departme'nt of Gerology. Arizona State University. Tempe, Arisoma 85287-1404, USA 


\section{IUGS financial statement for 1995 and budget for 1996 (US\$)}

1995

1996

I Income

Grants from ICSU fund

UNESCO IGCP contracts

UNESCO contribution to GARS

UNESCO contribution to Deposit Modelling 1

UNESCO contrribution to Climates of the Past ${ }^{1}$

UNESCO workshop on waste disposal!

UNESCO for Episodes

UNESCO Earthquake Losses

Contributions from National Members 2

Contributions from Associate Members

US contribution to IGCP and related projects

UK contribution to IGCP and related projects 1996

700.00

141100.00

0.00

0.00

6000.00

11000.00

3000.00

$2701 \overline{00} .00$

1100.00

80000.00

45249.00

Grants/donations

Bank interests

Sales of publications, royalties

10000.00

11159.23

1908.70

12.45

Miscellaneous receipts

138.77

Total

Carry-over from 1995 to 1996

Total receipts

600468.15

20800.00

138200.00

9000.00

8000.00

3000.00

3000.00

3800.00

240000.00

9000.00

80000.00

$45249.00^{3}$

5000.00

565049.00

39900.00

2. Expenditure

2.1 Scientific activities

IUGS Commissions, Boards, Committees, Working Groups (Schedule A)

71842.95

69500.00

Research projects:

- IGCP projects

- GARS 1

- Deposit Modelling

- Climates of the Past

- Earthquake Losses

- Workshop on waste disposal

- Inter-Union Commission on the Lithosphere

- Working Group on Landslides

- ICSU Programs 4

Grants to affiliated organizations (Schedule B)

IUGS contribution to:

- ICSU

- ICSTI for $1995^{5}$

- ICSTI for 1996

2.2 Meetings, conferences

Routine meetings

Scientific meetings

275800.00

9000.00

18000.00

14000.00

3000.00

20000.00

1000.00

11500.00

7405.00

642.96

691.79

29196.93

1150.00

2.3 Publications

Episodes ${ }^{6}$

45000.00

2.4 Administrative expenses

Operating costs and supplies

Miscellaneous expenses, audit

Bank charges

Contingency

1500.00

7767.18

3400.23

6784.59

Total expenses.

537681.63

Transfer to reserve account ${ }^{7}$

Total expenses including transfer to reserve account

3 Excess of income over expenditure

62786.52

274249.00

15000.00

11000.00

3400.00

3800.00

3000.00

20000.00

300.00

54700.00

5500.00

7762.00

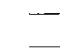

25000.00

3000.00

45000.00

2000.00

8000.00

4000.00

39738.00

$\mathbf{5 9 4 9 4 9 . 0 0}$

10000.00

604949.00

77302.49

101887.31

38300.00

6000.00

32300.00

Excess of receivable over payable

75201.69

Transfer to reserve account

16358.08

Status of account"

4.4 Trondheim account ${ }^{10}$ 


\section{Notes on the 1995 financial statement}

The financial statement is based on the ICSU guidelines and gives information about the IUGS accounts in Hannover and Reston; it does not include the local currency account in Moscow.

1 - 51 projects were funded by UNESCO in 1995. Of these, nine were decentralised, i.e. the funds were transferred directly from UNESCO to the respective project leaders.

- The UNESCO allocations for GARS and Deposit Modeling for 1995 were not received during 1995.

- The $\$ 6000$ allocation to Climates of the Past is the final payment for 1994.

- The UNESCO allocation for Climates of the Past for 1995 was not received during 1995.

- The allocation for the Workshop on Waste Disposal was decided during 1995 , therefore it is not included in the 1995 budget (see Episodes vol. 18 no. 3 ).
2 Member countries pay annual contributions according to their selected category of membership as outlined in the following table:

$\begin{array}{lrrrrrrrr}\text { Category } & 1 & 2 & 3 & 4 & 5 & 6 & 7 & 8 \\ \text { Contribution* } & 1 & 2 & 4 & 7 & 12 & 29 & 35 & 70 \\ \text { * valucd at US } \$ 400.00 \text { per unit as of July } & 15, & 1989 .\end{array}$

According to the decision of the IUGS Council at its meeting in Washington in July 1989 , all countries delinquent in paying their annual dues for more than two years will be deemed inactive. To regain active status, dues for the current year plus previous two years must be paid. All other previous pending dues will then be waived automatically. At December 31 , 1995, outstanding payments of active members totalled $\$ 18400$.

3 The UK contribution to IGCP for 1996 was received during 1995.
4 Including carry-over of $\$ 33900$ from 1994 and 1995.

5 The ICSTI contribution for 1996 was paid by IUGS in 1995.

6 IUGS payments to Episodes represent support for printing and related costs.

7 Transfer to the reserve account for the year 1995 (see item 4.2).

8 Includes carry-over of ICSU programs from the year 1995; the 1996 UK contribution to IGCP, and IGCP funds in the total amount of $\$ 85149$.

9 Invested in security bonds, the exact value of which will be given when payment is duc. During 1995 the Hutchison fund increased by $\$ 10000$. These funds do not appear in item 4.3 as they were still in the Reston current account at the end of the year.

10 Expenses in 1995 were paid by the Geological Survey of Norway.

\section{Schedule A Payments to Commissions}

\begin{tabular}{lr} 
& \multicolumn{1}{c}{1995} \\
\cline { 2 - 2 } CIMP & - \\
COGEOINFO & 10000.00 \\
INHIGEO & 4250.00 \\
Marine Geology & 3000.00 \\
Systematics in Petrology & 5000.00 \\
COMTEC & 3000.00 \\
Stratigraphy & \\
Commission on & 26815.00 \\
Comparative Planetology b & - \\
Global Sedimentary Geology & 2000.00 \\
COGEOED & - \\
Fossil Fuels & - \\
COGEOENVIRONMENT & 13000.00 \\
ABRD & 2735.29 \\
ABP & 2042.66 \\
\cline { 2 - 2 } Total & 71842.95
\end{tabular}

budget 1996

\begin{tabular}{c|l}
12000.00 & AGID \\
2000.00 & CGMW \\
- & GSAf \\
5000.00 & CBGA \\
4500.00 & IAMG \\
25000.00 & Permafrost \\
& Total
\end{tabular}

2000.00

1500.00

2000.00

12500.00

2000.00

1000.00

69500.00

\section{Schedule B Payments to Affiliated Organizations}

\begin{tabular}{lr} 
& \multicolumn{1}{c}{1995} \\
AGID & 3000.00 \\
CGMW & 2500.00 \\
GSAf & 3500.00 \\
CBGA & 1000.00 \\
IAMG & 1000.00 \\
Permafrost & 500.00 \\
Total & 11500.00
\end{tabular}

a (Schedule A) The International Commission on Stratigraphy received an overpayment of $\$ 1815$. This sum will be deducted in 1996 .

b The Commission on Comparitive Planetology received $\$ 2000$. for 1995, out of the contingency after evaluation by the ABRD. c For COGEOED $\$ 5000$ are reserved in the contingency. 


\section{James Hutton plaque fund}

As part of the bicentenary celebrations in 1997, it is proposed to erect and unveil a plaque to James Hutton on the site of the house on St John's Hill in Edinburgh, Scotland, where he wrote The theory of the Earth and all his other works.

A special fund to defray the cost has been established by the Edinburgh Geological Society and contributions are invited. Donations, made payable to the Edinburgh Geological Society, should be sent to the Hon. Treasurer, Dr David Gould, British Geological Survey, Murchison House, West Mains Road, Edinburgh EH9 3LA, UK.

It is intended to unveil the plaque during the international bicentenary

Hutton-Lyell meeting organised by the Royal Society of Edinburgh and the Geological Society in August 1977.

Norman E Butcher

Chairman, Edinburgh Geological Society.

\section{Subcommission on Carboniferous stratigraphy}

The next Field and General Meeting of SCCS will be held in Australia from 15th to 25 th September, 1997.

Following an initial general session at the University of New England in Armidale, New South Wales, $\sim 500 \mathrm{~km}$ north of Sydney, there will be a seven-day field trip through the two major segments of the southern New England Orogen.

The Central Complex of New England, a series of possibly allochthonous terranes and subduction comple $x$ rocks intruded by Late Carboniferous, Late Permian and Triassic granitoids will be examined during a half-day excursion from Armidale and on the first day of the field trip. The remainder of the trip will be spent examining Carboniferous rocks within the Tamworth Belt-marine and continental successions which accumulated in a forearc basin adjacent to a western continental volcanic arc.
All those interested in participating or obtaining further details concerning the meeting should contact one of the following:

\section{Professor John Roberts}

Chairman, SCCS, Department of Applied Geology University of New South Wales Sydney NSW 2052 Australia.

Phone: 61-2-385 4279; Fax: 61-2-385 5935; e-mail:J.Roberts@unsw.edu.au

\section{Dr Ian Metcalfe}

Secretary, SCCS, Department of Geology and Geophysics, University of New England, Armidale, NSW 2351, Australia. Phone: 61-67-73 2860; Fax: 61-67-73 3300;.e-mail:sccs@une.edu.au

\section{Dr Brian Engel}

Department of Geology, University of Newcastle, Newcastle NSW 2308, Australia. Phone: 61-49-21 5402; Fax: 61-49-21 6925, e-mail:bengel@geology.newcastle.edu.au

\section{Peter Cook}

\section{awarded CBE}

It has been announced in the 1996 Queen's Birthday Honours list that Dr Peter Cook, Director of the British Geological Survey. has been made a Commander of the Order of the British Empire in recognition of his scientific services to industry.

Dr Cook is an international geologist holding degrees from universities in the UK, Australia and USA. Before joining BGS in 1990, he worked in Australia for many years in academia, industry and government. He is a member of many national and international boards and committees.

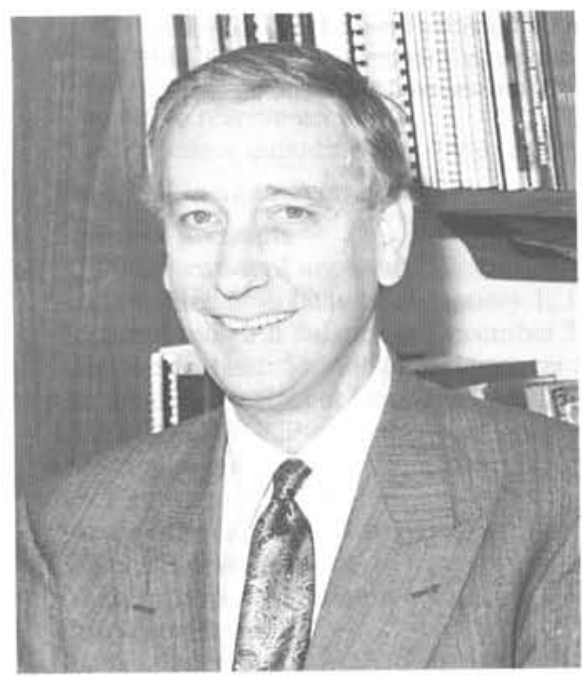

Dr Peter Cook

\section{Guess who?}

\section{A new competition}

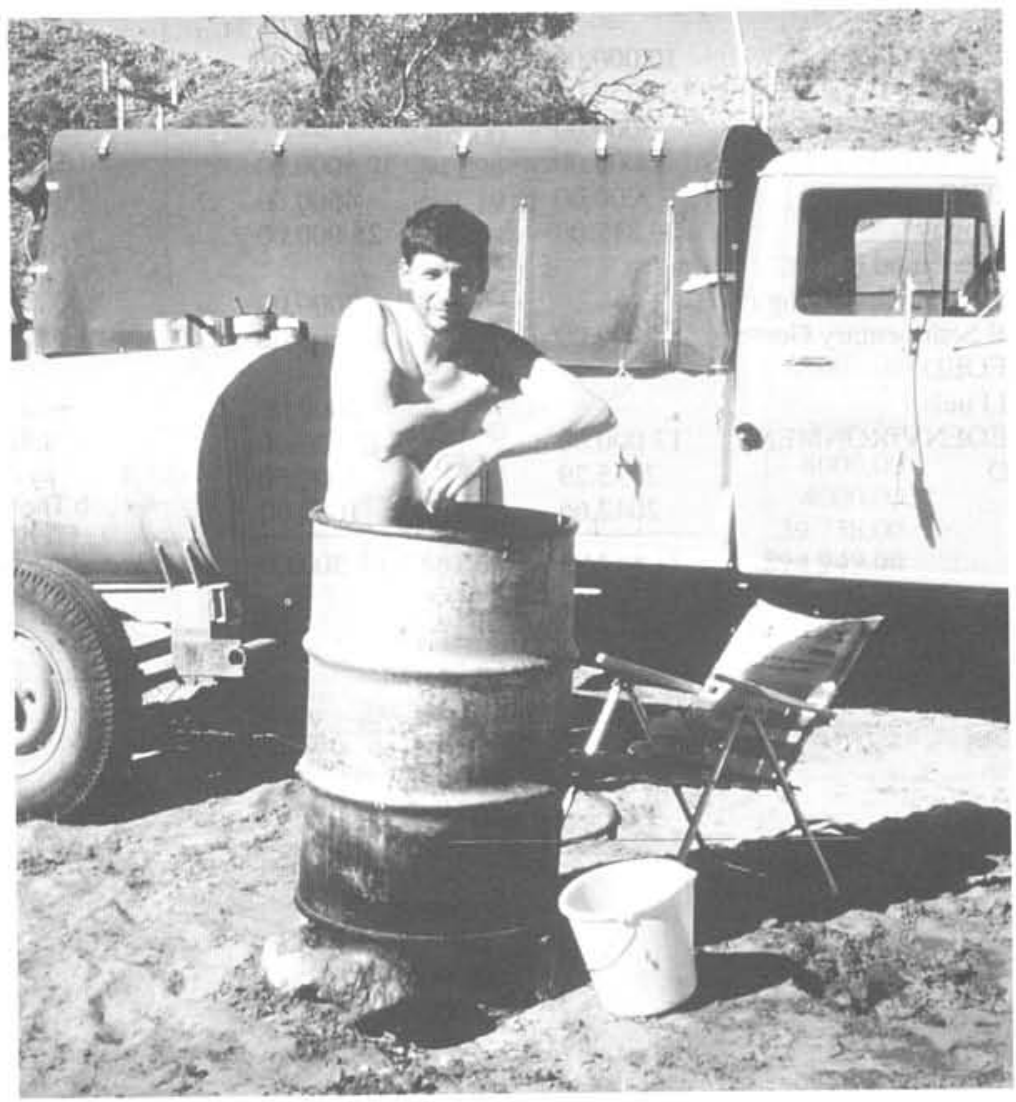

A well-known geoscientist cooling off after a long day's work in the field but who is he? A signed photograph of the Editor for the first correct answer: 